\title{
Idiosyncratic liver pigment alterations of five frog species in response to contrasting land use patterns in the Brazilian Cerrado
}

\author{
Lilian Franco-Belussi ${ }^{\text {Corresp., } 1,2}$, Diogo B Provete ${ }^{1,3}$, Rinneu E Borges ${ }^{2,4}$, Classius De Oliveira $^{2}$, Lia Raquel S Santos ${ }^{5}$ \\ 1 Instituto de Biociências, Universidade Federal de Mato Grosso do Sul, Campo Grande, Mato Grosso do Sul, Brazil \\ 2 Departamento de Biologia, Universidade Estadual Paulista, São José do Rio Preto, São Paulo, Brazil \\ 3 Gothenburg Global Biodiversity Centre, Gothenburg, Västra Götaland, Sweden \\ 4 Departamento de Biologia, Universidade de Rio Verde, Rio Verde, Goias, Brasil \\ 5 Instituto Federal de Educação, Ciência e Tecnologia Goiano, Rio Verde, Goias, Brasil \\ Corresponding Author: Lilian Franco-Belussi \\ Email address: lilian.belussi@gmail.com
}

Background. Changes in land use trigger environmental changes that can lead to decreased biodiversity and species loss. The liver is an essential detoxification organ that reflects systemic physiological responses to environmental changes. Here, we tested whether contrasting land use patterns influence the amount of substances from the hepatic cellular catabolism and melanomacrophages of five anuran species in the Brazilian Cerrado.

Methods. We collected the same five species of pond-dwelling frogs in one protected area and in an area with intense agricultural activity. We used routine histological and histochemical techniques to quantify the area occupied by lipofuscin, melanin, and hemosiderin in the liver of two frogs Leptodactylus fuscus, Physalaemus cuvieri, and three tree-frogs Dendropsophus minutus, Scinax fuscomarginatus, and Boana albopunctata. We classified land use types in a buffer around each pond based on satellite images. We then use a double-constrained Correspondence Analysis, a recently developed ecological method to relate functional traits to environmental variables, to test the effect of each land use type on the area of each liver pigment.

Results. There was an increase in the amount of melanin in environments with high proportion of agriculture, as well as variation in the amount of lipofuscin and hemosiderin. Liver pigments of Physalaemus cuvieri and Boana albopunctatavaried more strongly in response to land use types, suggesting they could be good indicator species. Therefore, the area of melanomacrophages in the liver and the metabolic products in their cytoplasm can be used as biomarkers of environmental changes in regions with intense agricultural activities. Our results add a new perspective to the influence of land use patterns on environmental health by highlighting the effect of environmental changes on internal morphological aspects of animals. 
1 Idiosyncratic liver pigment alterations of five frog species in response to contrasting land

2

3

4

5

6

$7{ }^{1}$ Departamento de Biologia, Universidade Estadual Paulista, São José do Rio Preto, São Paulo, 8 Brazil.

$9{ }^{2}$ Instituto de Biociências, Universidade Federal de Mato Grosso do Sul, Campo Grande, Mato

\section{use patterns in the Brazilian Cerrado} Raquel de Souza Santos 5

Grosso do Sul, Brazil.

${ }^{3}$ Gothenburg Global Biodiversity Centre, Gothenburg, Västra Götaland, Sweden.

${ }^{4}$ Departamento de Biologia, Universidade de Rio Verde, Rio Verde, Goiás, Brazil.

${ }^{5}$ Instituto Federal de Educação Ciência e Tecnologia Goiano, Rio Verde, Goiás, Brazil;

Corresponding author:

Lilian Franco-Belussi

Avenida Costa e Silva, s/n, Instituto de Biociências, Universidade Federal de Mato Grosso do Sul, Campo Grande, Mato Grosso do Sul, 79002-970, Brazil.

Email address: lilian.belussi@gmail.com

${ }^{6}$ Present address: Instituto de Biociências, Universidade Federal de Mato Grosso do Sul, Campo Grande, Mato Grosso do Sul, Brazil. 


\section{Abstract}

Background. Changes in land use trigger environmental changes that can lead to decreased biodiversity and species loss. The liver is an essential detoxification organ that reflects systemic physiological responses to environmental changes. Here, we tested whether contrasting land use patterns influence the amount of substances from the hepatic cellular catabolism and melanomacrophages of five anuran species in the Brazilian Cerrado.

Methods. We collected the same five species of pond-dwelling frogs in one protected area and in an area with intense agricultural activity. We used routine histological and histochemical techniques to quantify the area occupied by lipofuscin, melanin, and hemosiderin in the liver of two frogs Leptodactylus fuscus, Physalaemus cuvieri, and three tree-frogs Dendropsophus minutus, Scinax fuscomarginatus, and Boana albopunctata. We classified land use types in a buffer around each pond based on satellite images. We then use a double-constrained Correspondence Analysis, a recently developed ecological method to relate functional traits to environmental variables, to test the effect of each land use type on the area of each liver pigment.

Results. There was an increase in the amount of melanin in environments with high proportion of agriculture, as well as variation in the amount of lipofuscin and hemosiderin. Liver pigments of Physalaemus cuvieri and Boana albopunctata varied more strongly in response to land use types, suggesting they could be good indicator species. Therefore, the area of melanomacrophages in the liver and the metabolic products in their cytoplasm can be used as biomarkers of environmental changes in regions with intense agricultural activities. Our results add a new perspective to the influence of land use patterns on environmental health by highlighting the effect of environmental changes on internal morphological aspects of animals. 
45 Keywords: Melanomacrophages. Bioindicators. Environmental Stressors. Internal pigmentation.

46 Melanin. Liver metabolism. 
48

49

\section{Introduction}

Human-driven land use changes are causing biodiversity loss around the world (Newbold et al. 2015; Powers and Jetz, 2019). Brazil is one of the countries with the highest proportion of net loss of tree cover in South America, with a loss of 8\% from 1982 to 2016 (Song et al., 2018). At the same time, there was a $12 \%$ increase in short vegetation cover (Song et al., 2018), which includes shrubs and herbaceous vegetation. This trend was especially significant in the Brazilian Cerrado, of which less of 2\% are protected (Beuchle et al. 2015; Françoso et al., 2015; Damasco et al., 2018). Accordingly, more than half of the original 2 million $\mathrm{km}^{2}$ of the Cerrado were transformed into planted pastures and annual cultures by 2005 (Klink and Machado, 2005). Central Brazil is a thriving region for industrial agricultural activities (Dias et al. 2016) as one of the largest exporters of soybean and cattle meat in the world (Contini and Martha 2010, Reynolds et al., 2016). One of the consequences of land use change for export-oriented agricultural activities is the intensive use of agrochemicals (Schiesari et al., 2013; Aranha and Rocha, 2019). Therefore, land use changes, along with agrochemicals, are currently the main threats for biodiversity conservation and the sustainable use of natural resources in this biome (Reynolds et al., 2016).

Water quality in the Cerrado has been drastically affected by the intense use of fertilizers, with a significant increase in nitrogen and pesticides (Hunke et al., 2015). As a result, freshwater habitats receive a great load of contaminants, which impact several aspects of aquatic biodiversity (De Marco et al., 2013; Bichsel et al., 2016). For example, there is evidence that the replacement of natural habitats by urban and agricultural areas decrease not only amphibian populations, but also their genetic diversity (Eterovick et al., 2016). Additionally, land use changes can promote rapid transformation in biological communities beyond species composition. Specifically, it can alter phenotypic aspects of several animal groups (e.g., Borges et al., 2019a), which impact how 
71 species interact and adapt to a changing environment. These phenotypic changes include DNA 72 damages (Borges et al., 2019b) and developmental abnormalities (Borges et al., 2019a). However,

73 little is known about the effects of contrasting land uses on internal phenotypic aspects of 74 organisms inhabiting Neotropical agroecosystems.

Amphibians are good bioindicators of environmental quality because they show rapid responses to environmental stress (Halliday 2000, Brodeur and Candioti, 2017). In addition, they have permeable skin and eggs, making them vulnerable to aquatic contamination and infections. As such, these animals are useful for monitoring changes in both the aquatic and terrestrial environments because they depend on the two environments to complete their life cycle (Brodeur and Candioti, 2017). Amphibians are rapidly declining worldwide due to human-induced changes in the environment (Catenazzi, 2015; Alton and Franklin, 2017). Several factors are involved in this decline, including climate change, increased incidence of ultraviolet (UV) radiation due to ozone depletion, invasive species, environmental contamination, diseases, and habitat change or loss (Collins and Crump, 2009; Alton and Franklin, 2017).

Previous studies have analyzed the effects of agrochemicals on tadpole developmental abnormalities (Borges et al., 2019a) or genotoxic effects in adult anurans. However, environmental alterations that promote morphological and physiological changes at the tissue level are poorly understood. The liver plays a key role in the detoxification of xenobiotics (Pérez-Iglesias, et al., 2018; Fanali et al., 2018), as well as other functions related to the metabolism (Hinton et al., 2001; Fenoglio et al., 2005). The detoxification is performed by hepatocytes and melanomacrophages and may be either enzymatic or not. Melanomacrophage centers and their pigments (melanin,

92 lipofuscin, and hemosiderin) are involved in the hepatic response to various toxic compounds. 
93 Thus, the liver is an important organ to evaluate the response of organisms to environmental 94 pollutants (Fenoglio et al., 2005).

Melanomacrophages (MMs) are cells that occur in the hepatic tissue and produce and store

96 melanin in their cytoplasm. The area and occurrence of melanomacrophages in the liver increase

97 in response to environmental stressors, such as temperature (Santos et al., 2014), UV radiation

98 (Franco-Belussi et al., 2016), and xenobiotics (Çakıc1 2015; Pérez-Iglesias et al., 2016). In addition

99 to melanin, MMs contain catabolic substances originated from the degradation of red blood cells:

100 hemosiderin and lipofuscin, originated from the degradation of polyunsaturated membrane lipids

101 (Oliveira and Franco-Belussi 2012). Therefore, the density of melanomacrophages can be a useful

102 morphological biomarker for the effect of environmental stressors (De Oliveira et al., 2017).

103 Morphofunctional changes in the hepatic parenchyma happen as a result of contaminants, 104 suggesting the action of detoxification by melanomacrophages due to the processing action of 105 some enzymes, besides the protective action of melanin (Fenoglio et al., 2005). Additionally, the 106 functions of melanomacrophages are also related to the maintenance of homeostasis, regulating 107 fibrosis, controlling basophiles, and participating in the recycling of red blood cells (Gutierre et 108 al. 2018).

Changes in the amount of catabolic substances within melanomacrophages may be associated with changes in phagocytic activity (Bucke et al., 1992; Fenoglio et al., 2005). For example, lipofuscin is produced as a result of the degradation of cellular components. Thus, its

112 increase may hinder cell renewal and promote an accumulation of damaged cellular components 113 in the tissue. The accumulation of lipofuscin can increase cellular sensitiveness to oxidative stress,

114 since this molecule binds to metals, such as iron and copper (Terman and Brunk, 2004). 115 Hemosiderin is an intermediate metabolite generated during the recycling of components in blood 
116 production. Thus, the accumulation of hemosiderin indicates a disorder in blood cell recycling

117 (Pérez-Iglesias et al., 2016). In addition, environmental factors that alter the concentration of these

118 substances in the liver may strongly contribute to the decrease in animal health. Consequently, this

119 can affect individual fitness and promote population decline in the long term. Therefore, analyzing

120 liver cell physiology may be useful for detecting the effects of environmental changes by human

121 actions. However, while previous studies (Franco-Belussi et al. 2013, Santos et al. 2014, Gregorio

122 et al. 2016, Pérez-Iglesias et al. 2016) have analyzed the variation of melanin, lipofuscin, and

123 hemosiderin in response to climatic factors and xenobiotics in laboratory experiments using model

124 species, no study has investigated how these three substances vary at the same time in response to

125 contrasting land use patterns in wild amphibian populations.

126 Here, we tested the influence of contrasting land use regimes associated with aquatic 127 contaminants on liver cell morphology and physiology of five frog species in the Brazilian 128 Cerrado. These can be hidden effects of changes associated with agricultural intensification that 129 are often neglected in biodiversity assessments that only consider species abundance and occurrence. We expect that frogs collected in ponds embedded in areas with intense agricultural activity will have increased hepatic metabolism because of potential aquatic contaminants, increased solar incidence and temperature. As a result, individuals will have higher amounts of melanin, due to its protective effects against free radicals in tissues, along with higher amounts of hemosiderin and lipofuscin, because these two substances reflect changes in hepatic metabolism.

\section{Material and methods}

\section{Study area and specimen sampling}


Field work was carried out in two regions: three ponds in the surroundings of Rio Verde

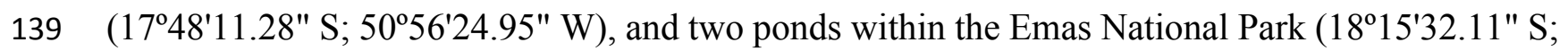
5253'14.13" W; Fig. 1), Goiás, central Brazil. The set of ponds were selected in both regions

141 because they had the same species composition, allowing us to compare the effects of contrasting 142 land use in a paired design (our dataset is available at Franco-Belussi et al. 2020). Ponds in the

143 National Park were selected based on a previous survey (Kopp et al. 2010) that sampled the same 144 ponds and recorded the presence of our target species. Sampling sites in the Rio Verde region were 145 selected because they were inserted into an agricultural matrix and also harbored the same species. 146 Ponds were separated by at least $1.25 \mathrm{Km}$ and a maximum of $3.20 \mathrm{Km}$ in Rio Verde and by 15.30 $147 \mathrm{Km}$ in the National Park. Samplings were conducted during the breeding season between 148 November 2013 and March 2014. Field work consisted of one week of sampling in each region 149 each year.

150 The region around the city of Rio Verde is a thriving agricultural area, mainly covered with 151 planted pastures, and monocultures of soybean, corn, and sorghum. The Emas National Park is an 152 enclave of Cerrado Protected Area with several typical vegetation types of this biome, varying 153 from open formation, such as campo limpo and campo rupestre, to closed-canopy formations, such as Cerradão and Seasonal Deciduous Forest (Valente 2006). The Instituto Chico Mendes de 155 Conservação da Biodiversidade provided colleting permit (Sisbio \#34485-1) and Emas National 156 Park provided housing and authorization for field work.

157 We used a paired design in which we collected five adult males of the following species in 158 each region: Boana albopunctata, Dendropsophus minutus, Scinax fuscomarginatus, 159 Leptodactylus fuscus, and Physalaemus cuvieri. These species were previously selected because 160 they occurred in both regions (Kopp et al. 2010). Additionally, all of them are widely distributed 
161 throughout South America (AmphibiaWeb, 2020) and seem to be generalists, occurring in a wide

162 range of habitats, from open, natural formations, to bush Savannas, to peri-urban areas (Haddad et 163 al. 2013). All species are classified as Least Concern in both the IUCN Red list (IUCN 2010) and 164 Brazilian National Red list (ICMBio 2018). Boana albopunctata, Scinax fuscomarginatus, and 165 Dendropsophus minutus are hylid tree-frogs that call perched on the vegetation, while 166 Leptodactylus fuscus and Physalaemus cuvieri are medium-sized leptodactylids that are found 167 calling and usually foraging on the ground near temporary ponds (Haddad et al. 2013). Both $B$. 168 albopunctata and D. minutus deposit egg masses directly on water, while L. fuscus and P. cuvieri 169 build foam nests in which they deposit eggs on the margin (in the case of P. cuvieri) or on 170 subterranean chambers (in the case of L. fuscus; Haddad et al. 2013) of water bodies. Thus, adults, 171 eggs, and larvae of these species have different degrees of contact with contaminated water. 172 Consequently, these species can potentially be useful as environmental indicators, since they are

173 highly abundant within their geographic range and seem to respond quickly to environmental 174 disturbance.

\section{Water quality analysis}

To test if the ponds used by amphibians were contaminated by pesticides, we collected 1-

L samples of water in one pond from each region. We took samples at approximately $10 \mathrm{~cm}$ depth from all ponds surveyed, but they were further grouped by region before analysis. We quantified organochlorines and organophosphates in only one water sample of each region. Samples were taken using a sterile, amber glass vial and immediately stored in ice at $4{ }^{\circ} \mathrm{C}$, then sent to the laboratory and analyzed within $24 \mathrm{~h}$. Quantification was made using standard methodology by 
183 A3Q Laboratory of Environmental Quality (Cascavel, Paraná, Brazil). Samplings from the Park

184 did not contain any substance above the references, while Rio Verde had atrazine well above the

185 level allowed by the Brazilian environmental agency (Table S1).

\section{Routine histological processing}

Specimens were anesthetized with $5 \mathrm{~g} / \mathrm{L}$ benzocaine. This procedure was approved by the ethics committee on animal use of our university (protocol \#0316, CEUA/UniRV). Liver fragments were extracted and fixed in metacarn solution for $3 \mathrm{~h}$. Subsequently, they were dehydrated in an alcoholic series and included in historesin $\left(\right.$ Leica $\left.^{\circledR}\right)$. We obtained $2 \mu \mathrm{m}$ sections in rotating microtome (RM 2265, Leica, Switzerland), which were stained with hematoxylin and eosin.

Histochemical analyzes were performed for the detection of lipofuscin as follows: sections were incubated for $15 \mathrm{~min}$ in Schmorl's solution, composed of $75 \mathrm{~mL}$ of $1 \%$ ferric chloride, 10 $\mathrm{mL}$ of potassium ferricyanide, and $15 \mathrm{~mL}$ of distilled water. Then, sections were immersed in neutral red aqueous solution at $1 \%$ followed by $1 \%$ aqueous solution of eosin. For the detection of hemosiderin, sections were incubated for $15 \mathrm{~min}$ in acid solution of ferrocyanide obtained by the dissolution of $2 \mathrm{~g}$ of potassium ferrocyanide in $100 \mathrm{~mL}$ of $0.75 \mathrm{~mol} / \mathrm{L}$ hydrochloric acid solution. Subsequently they were immersed in aqueous solution of $1 \%$ neutral red followed by aqueous solution of $1 \%$ eosin.

Images were captured in a digital camera coupled with a microscope (Laborana Lab50AB-

Cybernetics Inc.). Image analysis was conducted using 25 randomized histological fields for each 
206 intensity in 25 pictures per animal following Santos et al. (2014). Quantifications were done in a

207 double-blind fashion.

208

209 Quantification of land use pattern

210

To quantify land use, we used a shape file with land cover and use classes (IBGE, 2018

211

URL: http://www.sieg.go.gov.br/produtosIMB.asp?cod=4725). This file classifies land use and

212 cover into 14 classes based on satellite images from 2014 (see Appendix II in IBGE 2018). To calculate the area of each land use, we established a buffer of $500 \mathrm{~m}$ radius around each water body sampled and calculated the area occupied by each land use class in ArcGIS 9.0 software (ESRI 2011). This buffer size has been commonly used in studies of landscape ecology involving anurans (e.g., Almeida-Gomes et al. 2016), since it is usually the dispersal distance of individuals moving among ponds in agricultural landscapes. The areas of each land use class were then converted into proportions and used as predictor variables in further analyzes. The land use types we found around our sampling sites were: natural grassland and shrub vegetation, artificial area, forest mosaic, grassland mosaic, planted pastures, and natural pasture, and agricultural area. Since the area of some land use types in our data set was small, we combined artificial area with grassland mosaic into a class called anthropized area, and also combined forest mosaic, natural pastures, and agricultural area into a class called farming to improve data analysis and interpretation of results.

\section{Data analysis}

There are currently several methods to test the influence of environmental variables on species traits (see review in Kleyer et al., 2012), the so-called fourth-corner problem. However, there is still no consensus as to which method is best, and it seems that this decision is dependent 
229 on the context and trait data type (continuous, categorical or mixed), although studies show that

230 correlating Community-weighted Mean with environmental variables always seems to produce

231 larger Type I Errors (Peres-Neto et al., 2017; ter Braak et al., 2017). Here, we used a double-

232 constrained Correspondence Analysis (or dc-CA, for short) to test whether the mean area of

233 melanin, hemosiderin, and lipofuscin (response variables) of the five species are correlated with

234 different classes of land use (predictor variables). This is a method proposed long ago (Lebreton

235 et al., 1988), but a new algorithm has only recently been proposed (ter Braak et al., 2018). The

236 advantages of dc-CA are that it considers the correlation among environmental variables and

237 among traits, when relating traits to environment (see ter Braak et al., 2018), differently from RLQ

238 and CWM-RDA (see Kleyer et al. 2012).

239 dc-CA uses three tables: a species-by-site matrix $\mathbf{Y}$, which can contain either abundances

240 or incidence; a site-by-environment matrix $\mathbf{E}$, and a species-by-trait $\mathbf{T}$ matrix. The method starts

241 by conducting a Correspondence Analysis constraining both the columns (species) by species traits

242 and row scores of the Y matrix by environmental variables (ter Braak et al. 2018). We then

243 produced a triplot showing the relationship among traits, environmental variables, and species

244 incidence in a single ordination diagram. Analysis was conducted using R code (R Core Team

245 2010) available in the supplementary material of ter Braak et al. (2018) and Canoco 5.12 (ter Braak

246 and Šmilauer 2018). All data and an R Markdown dynamics document with code used to anlayze

247 the data is available at Franco-Belussi et al. (2020).

\section{Results}

250

The amount of each pigment varies among species (Fig. S1A), but P. cuvieri and B.

251 albopunctata had the highest areas of melanin, while D. minutus and L. fuscus had relatively more 
252 lipofuscin. We found both great intra- and interspecific variation in the amount of each substance

253 (Fig. 2). Most species had higher amounts of lipofuscin and melanin than hemosiderin, except

254 Boana albopunctata that had lower amounts of lipofuscin than the other species. Interestingly,

255 Leptodactylus fuscus and Dendropsophus minutus showed little intraspecific variation in the

256 amount of all three substances, while Physalaemus cuvieri and B. albopunctata had high

257 intraspecific variation. The means for the three substances was similar for L. fuscus and D. minutus,

258 whereas the other three species had very distinct means. Interestingly, the relative proportion of

259 the three pigments also varied between sampling regions, because animals from the agricultural

260 area had more melanin and lipofuscin, but less hemosiderin (Fig. S1B). Species whose liver

261 pigments more strongly varied between sampling regions were $P$. cuvieri, B. albopunctata, and $S$.

262 fuscomarginatus (Fig. 3).

263 The total inertia of the dc-CA model was 0.955 . The first axis of dc-CA accounted for $72 \%$

264 of the variation in the trait-environment relationship, while the second accounted for $26 \%$. The

265 maximized fourth-corner correlation along the first and second axes are 0.83 and 0.50 ,

266 respectively. Melanin was positively correlated with natural and planted pastures, but negatively

267 correlated with man-made buildings and agriculture (Table 1). Hemosiderin was negatively

268 correlated natural and planted pastures, and man-made buildings, but positively correlated with

269 agriculture. The correlation pattern of lipofuscin was almost identical to hemosiderin with small

270 changes in the strength of correlation with some land use types (Table 1).

271 The abundance of $P$. cuvieri was positively correlated with the percentage of planted

272 pasture in the landscape (Fig. 4). This was also the species with the highest amount of melanin in

273 the liver (Fig 4), which was positively correlated (fourth-corner correlation $=0.473$, Table 1 ) with

274 the percentage of planted pasture (Fig. 4). In contrast, L. fuscus had the lowest amount of melanin 
275 (Fig. 4) whose abundance was negatively correlated with the percentage of planted pasture in the 276 landscape (Fig. 4).

277 Conversely, the abundance of D. minutus and S. fuscomarginatus were positively 278 correlated with area of agriculture and negatively with anthropogenic area, while the abundance 279 of B. albopunctata was positively correlated with anthropogenic area and negatively with area of 280 agriculture (Fig. 4). Dendropsophus minutus and S. fuscomarginatus had higher amounts of 281 hemosiderin and lipofuscin, suggesting higher hepatic metabolism, which was positively 282 correlated with agriculture and negatively with percentage of anthropogenic area (Fig 4). 283 Conversely, B. albopunctata had fewer hepatic catabolite substances (Fig. 4).

285 Discussion

We found that $P$. cuvieri occurred in sites with planted pastures and man-made buildings, had higher amounts of melanin, while the abundance of L. fuscus was positively correlated with man-made buildings and negatively correlated with planted pastures. Additionally, D. minutus and hemosiderin and its abundance was positively correlated with man-made buildings. Taken together, these results demonstrate the effects of environmental changes on melanomacrophages and hepatic metabolism of frog species.

The amount of melanin was highest in P. cuvieri and B. albopunctata, but low in L. fuscus, of change in melanin within species between sampling regions. There was also a high positive correlation between melanin and planted pastures $(0.473)$, and a less strong correlation with manmade buildings (-0.033), and natural pastures (0.139). Melanin is a complex polymer that absorbs 
298 and neutralizes free radicals, besides participating in the innate immune response and protection

299 of tissues in ectotherms (Cesarini 1996). Changes in the amount of melanin was found in frogs

300 experimentally exposed to several xenobiotics. In these experiments, the variation in melanin was

301 due to several compounds (reviewed in De Oliveira et al. 2017), such as polycyclic aromatic

302 hydrocarbons (PAHs; Fanali et al. 2018), herbicides (e.g., atrazine and glyphosate; Pérez-Iglesias

303 et al. 2019; Bach et al. 2018), drugs, and endocrine disrupters (Gregorio et al. 2016). Here, we

304 found large amounts of atrazine in the area under agriculture influence (more than 5,000 time the

305 limit accepted by Brazilian legislation, i.e. $5349.940 \mu \mathrm{g} / \mathrm{L}$ ). Atrazine is an endocrine disruptor,

306 which has immunotoxic and immunosuppressive effects even at concentrations usually found in

307 the environment (i.e. $<500 \mu \mathrm{g} / \mathrm{L} ;$ Rohr ad McCoy 2010). This substance can change swimming

308 ability, cause malformations, and promote nuclear alterations at higher concentrations in tadpoles

309 (Pérez-Iglesias et al. 2019). Atrazine causes oxidative stress in several tissues, which can evolve

310 to function loss. The replacement of natural vegetation by agriculture can increase UV incidence

311 and temperature (Lipinski et al. 2016). This is an indirect effect of land use change that can affect

312 the amount of internal melanin in frogs.

313 Although our statistical model explained much variation in the three substances, other

314 climatic factors that have been changing because of human activities, such as temperature and

315 Ultra-violet radiation can also change the amount of melanin in internal tissues of frogs (Franco-

316 Belussi et al. 2017). Changes in these environmental variables may promote changes in hepatic

317 metabolism, such as increasing glycogen and lipid levels (Mizell, 1965; Barni and Bernocchi,

318 1991; Fenoglio et al. 1992, Barni et al. 2002). Adaptation to natural conditions (i.e., hibernation)

319 may promote an increase in the amount of melanin in the liver by increasing the number of cells

320 (i.e. hyperplasia) or the increase in cell size (i.e. hypertrophy), besides an increase in the production 
321 of melanin in cell interior (Barni et al. 2002). These changes occur as a mechanism of metabolic

322 defense against free radicals. For example, with increased storage of lipids and glycogen in hepatic

323 tissue due to environmental changes that occur naturally in hibernating animals (Mizell, 1965;

324 Barni and Bernocchi, 1991; Fenoglio et al. 1992, Barni et al. 2002). Thus, the liver of anurans is

325 a plastic organ, besides being sensitive to the alterations of the natural biological rhythms (i.e.

326 reproduction and hibernation), coordinating these mechanisms to maintain the homeostasis of the

327 organism during adaptation to environmental changes (Barni et al. 2002). Therefore, cells that

328 produce and store melanin seem to be involved in the adaptation to environmental stressors at the

329 tissue level.

Dendropsophus minutus and $S$. fuscomarginatus had high amounts, whereas $B$.

331

332

333

334

335

336

337

338

339

340

341

342

343

albopunctata had low amounts of hemosiderin and lipofuscin. Lipofuscin and hemosiderin are products of cellular catabolism and can be used to measure hepatic metabolism, since both substances may be altered as a result of environmental stress following habitat alteration (Santos et al. 2014, Pérez-Iglesias et al. 2016). Low amounts of these substances indicate decreased phagocytic activity of cells (Bucke et al. 1992; Fenoglio et al. 2005), while accumulation of hemosiderin is related to increased turnover of blood cells (Fenoglio et al. 2005). Therefore, the increase in recycling of blood cells in D. minutus and S. fuscomarginatus indicates that biotic or abiotic factors resulting from anthropic changes may be causing changes in the liver of these two species, but less so in B. albopunctata.

The idiosyncratic responses of species may be related to differences in life history traits. Internal melanin varies among species and organs in anurans, possibly due to its adaptive function conferred by the protective functions of the pigment (Provete et al. 2012; Franco-Belussi et al. 2017). For example, Physalaemus and Leptodactylus are terrestrial and can have more contact with 
344 xenobiotics; while Boana, Scinax, and Dendropsophus are arboreal and putatively less exposed to

345 aquatic xenobiotics (Silva et al. 2013). However, it is noteworthy that any drastic change in land

346 use appears to promote metabolic alterations related to liver physiological processes in anurans.

347 Therefore, MMCs seem to be efficient biomarkers indicating alterations in the liver in response to

348 contrasting land use types. Actions for mitigating the negative effects of industrial agricultural

349 activities must be taken if we want to reach the goal of making environmentally responsible

350 agricultural products (ONU 2050 goals), especially in grassy biomes (Parr et al. 2014, Overback

351 et al. 2015).

352

353 Conclusion

Our a priori hypothesis was that frogs from the area with intense agricultural activity would

have higher amounts of melanin, hemosiderin, and lipofuscin, because of the increase in hepatic

metabolism necessary to deal with potential contaminants and higher solar incidence promoted by

loss of vegetation cover. We found that the amount of melanin, hemosiderin, and lipofuscin indeed

varied between regions, but each species seemed to respond differently to these contrasting lands

use types. The species whose liver metabolism most changed across different land use type were

Physalaemus cuvieri, Boana albopunctata, and Scinax fuscomarginatus. Therefore, these species

should be used for evaluating environmental alterations. Aquatic contaminants may alter organismal health that cannot be assessed by only recording species presence in each environment, since the internal morphology of individuals can be damaged. Alterations in hepatic metabolism can compromise population viability and species persistence in the environment in the long term. physiology) in environmental monitoring programs. 


\section{Acknowledgements}

B. Valverde, W. R. Rezende, R. A. Assis, and G. Leite helped with histological procedures.

R. F. Oliveira kindly prepared the map shown in Figure 1. M. Almeida-Gomes helped with GIS aspects of analysis.

373

\section{References}

375

376

377

378

379

380

381

382

383

384

385

386

387

388

Almeida-Gomes M, Rocha CF, Vieira MV. 2016. Local and landscape factors driving the structure of tropical anuran communities: Do ephemeral ponds have a nested pattern? Biotropica 48:365372.

Alton LA, Franklin CE. 2017. Drivers of amphibian declines: effects of ultraviolet radiation and interactions with other environmental factors. Climate Change Responses 4:6.

AmphibiaWeb. 2020. Available at: http://amphibiaweb.org. University of California, Berkeley, CA, USA. (Accessed 1 Jun 2020).

Aranha A, Rocha L. 2019. “Coquetel” com 27 agrotóxicos foi achado na água de 1 em cada 4 municípios. Reporter Brasil, São Paulo. Available at: https://reporterbrasil.org.br/2019/04/coquetel-com-27-agrotoxicos-foi-achado-na-agua-de-1em-cada-4-municipios/

Bach NC, Marino DJ, Natale GS, Somoza GM. 2018. Effects of glyphosate and its commercial formulation, Roundup ${ }^{\circledR}$ Ultramax, on liver histology of tadpoles of the neotropical frog, Leptodactylus latrans (amphibia: Anura). Chemosphere 202:289-297. 
389

390

391

392

393

394

395

396

397

398

399

400

401

402

403

404

405

406

407

408

409

410

Barni S, Vaccarone R, Bertone V, Fraschini A, Bernini F, Fenoglio C. 2002. Mechanisms of changes to the liver pigmentary component during the annual cycle (activity and hibernation) of Rana esculenta L. Journal of anatomy 200:185-194.

Barni S, Bernocchi G. 1991. Internalization of erythrocytes into liver parenchymal cells in naturally hibernating frogs (Rana esculenta L.). Journal of Experimental Zoology 258:143-150.

Beuchle R, Grecchi RC, Shimabukuro YE, Seliger R, Eva HD, Sano E, Achard F. 2015. Land cover changes in the Brazilian Cerrado and Caatinga biomes from 1990 to 2010 based on a systematic remote sensing sampling approach. Applied Geography 58:116-127. 10.1016/j.apgeog.2015.01.017

Bichsel D, De Marco P, Bispo AA, Ilg C, Dias-Silva K, Vieira TB, Correa CC, Oertli B. 2016. Water quality of rural ponds in the extensive agricultural landscape of the Cerrado (Brazil). Limnology 17:239-246. 10.1007/s10201-016-0478-7

Borges RE, de Souza Santos LR, Assis RA, Benvindo-Souza M, Franco-Belussi L, de Oliveira C. 2019a. Monitoring the morphological integrity of neotropical anurans. Environmental Science and Pollution Research 26:2623-2634.

Borges RE, de Souza Santos LR, Benvindo-Souza M, Modesto RS, Assis RA, de Oliveira C. 2019b. Genotoxic evaluation in tadpoles associated with agriculture in the Central Cerrado, Brazil. Archives of environmental contamination and toxicology 77:22-28.

Brodeur JC, Vera Candioti J. 2017. Impacts of Agriculture and Pesticides on Amphibian Terrestrial Life Stages: Potential Biomonitor/Bioindicator Species for the Pampa Region of Argentina. In: Larramendy ML, ed. Ecotoxicology and Genotoxicology: Non-traditional Terrestrial Models. London: The Royal Society of Chemistry, 163-194. 
411 Bucke D, Vethaak A, Lang T. 1992. Quantitative assessment of melanomacrophage centres

412 (MMCs) in dab Limanda limanda along a pollution transect in the German Bight. Marine 413 Ecology Progress Series:193-196.

414 Çakıcı Ö. 2015. Histopathologic changes in liver and kidney tissues induced by carbaryl in Bufotes 415 variabilis (Anura: Bufonidae). Experimental and Toxicologic Pathology 67:237-243.

416 Catenazzi A. 2015. State of the world's amphibians. Annual Review of Environment and Resources $417 \quad 40: 91-119$.

418 Cesarini J. 1996. Melanins and their possible roles through biological evolution. Advances in $419 \quad$ Space Research 18:35-40.

420 Collins JP, Crump ML. 2009. Extinction in our times: global amphibian decline. New York: 421 Oxford University Press.

422 Contini E, Martha Jr. G.B. 2010. Brazilian agriculture, its productivity and change. Paper 423 presented at Bertebos Conference on "Food security and the futures of farms: 2020 and toward 424 2050”, Falkenberg: Royal Swedish Academy of Agriculture and Forestry, August 29-31, 2010. 425 Damasco G, Fontes C, Françoso R, Haidar R. 2018. The Cerrado biome: a forgotten biodiversity 426 hotspot. Frontiers for Young Minds 6.

427 De Marco P, Nogueira DS, Correa CC, Vieira TB, Silva KD, Pinto NS, Bichsel D, Hirota ASV, 428 Vieira RRS, Carneiro FM, de Oliveira AAB, Carvalho P, Bastos RP, Ilg C, Oertli B. 2013. 429 Patterns in the organization of Cerrado pond biodiversity in Brazilian pasture landscapes. $430 \quad$ Hydrobiologia 723:87-101. 10.1007/s10750-013-1695-2

431 De Oliveira C, Franco-Belussi L, Fanali LZ, Santos LRS. 2017. Use of Melanin-pigmented Cells 432 as a New Tool to Evaluate Effects of Agrochemicals and Other Emerging Contaminants in 
433

434

435

436

437

438

439

440

441

442

443

444

445

446

447

448

449

450

451

452

453

454

455

Brazilian Anurans. In: Larramendy ML, ed. Ecotoxicology and Genotoxicology: Nontraditional Terrestrial Models. London: The Royal Society of Chemistry, 123-142.

Dias LC, Pimenta FM, Santos AB, Costa MH, Ladle RJ. 2016. Patterns of land use, extensification, and intensification of Brazilian agriculture. Glob Chang Biol 22:2887-2903. $10.1111 / \mathrm{gcb} .13314$

Environmental Systems Research Institute (ESRI). 2011. ArcGIS Desktop: Release 9. Redlands: Environmental Systems Research Institute. Available at: http://resources.arcgis.com/en/help/main/10.2/index.html.

Eterovick PC, Sloss BL, Scalzo JAM, Alford RA. 2016. Isolated frogs in a crowded world: Effects of human-caused habitat loss on frog heterozygosity and fluctuating asymmetry. Biological Conservation 195:52-59. 10.1016/j.biocon.2015.12.036

Fanali LZ, Franco-Belussi L, Bonini-Domingos CR, de Oliveira C. 2018. Effects of benzo [a] pyrene on the blood and liver of Physalaemus cuvieri and Leptodactylus fuscus (Anura: Leptodactylidae). Environmental pollution 237:93-102.

Fenoglio C, Boncompagni E, Fasola M, Gandini C, Comizzoli S, Milanesi G, Barni S. 2005. Effects of environmental pollution on the liver parenchymal cells and Kupffermelanomacrophagic cells of the frog Rana esculenta. Ecotoxicology and environmental safety $60: 259-268$

Fenoglio C, Bernocchi G, Barni S. 1992. Frog hepatocyte modifications induced by seasonal variations: a morphological and cytochemical study. Tissue and Cell 24:17-29.

Franco-Belussi L, de Lauro Castrucci AM, de Oliveira C. 2013. Responses of melanocytes and melanomacrophages of Eupemphix nattereri (Anura: Leiuperidae) to Nle4, D-Phe7- $\alpha$ melanocyte stimulating hormone and lipopolysaccharides. Zoology 116:316-324. 
456 Franco-Belussi L, Sköld HN, de Oliveira C. 2016. Internal pigment cells respond to external UV

457 radiation in frogs. Journal of Experimental Biology 219:1378-1383.

458 Franco-Belussi L, Provete DB, De Oliveira C. 2017. Environmental correlates of internal 459 coloration in frogs vary throughout space and lineages. Ecology and Evolution 7:9222-9233. $460 \quad 10.1002 /$ ece 3.3438

461 Franco-Belussi L, Provete DB, Borges R, De Oliveira C, Santos LR. 2020. Idiosyncratic liver 462 pigment alterations of five frog species in response to contrasting land use patterns in the 463 Brazilian Cerrado, Mendeley Data, v4 http://dx.doi.org/10.17632/bcsm7v629y.4

464 Françoso RD, Brandão R, Nogueira CC, Salmona YB, Machado RB, Colli GR. 2015. Habitat loss 465 and the effectiveness of protected areas in the Cerrado Biodiversity Hotspot. Natureza \& 466 Conservação 13:35-40. 10.1016/j.ncon.2015.04.001

467 Gregorio LSd, Franco-Belussi L, Gomes FR, de Oliveira C. 2016. Flutamide effects on 468 morphology of reproductive organs and liver of Neotropical Anura, Rhinella schneideri. $469 \quad$ Aquatic Toxicology 176:181-189.

470 Gutierre RC, Jared C, Antoniazzi MM, Coppi AA, Egami MI. 2018. Melanomacrophage functions 471 in the liver of the caecilian Siphonops annulatus. Journal of anatomy 232:497-508.

472 Haddad CF, Toledo LF, Prado CPA, Loebmann D, Gasparini JL, Sazima I. 2013. Guia dos 473 Anfíbios da Mata Atlântica: diversidade e biologia. São Paulo: Anolis Books.

474 Halliday T. 2000. Do frogs make good canaries? Biologist 47:143-146.

475 Hinton DE, Segner H, Braunbeck T. 2001. Toxic responses of the liver. In: Schlenk D, and Benson $476 \mathrm{WH}$, eds. Target organ toxicity in marine and freshwater teleosts. New York: Taylor and $477 \quad$ Francis, 224-268. 
478 Hunke P, Mueller EN, Schröder B, Zeilhofer P. 2014. The Brazilian Cerrado: assessment of water 479 and soil degradation in catchments under intensive agricultural use. Ecohydrology 8:1154-1180. $480 \quad 10.1002 /$ eco. 1573

481 IBGE, 2018. Mudanças na cobertura e uso da terra do Brasil 2014 - 2016. Instituto Brasileiro de 482 Geografia e Estatística, Rio de Janeiro, Brazil. Available at: 483 https://www.ibge.gov.br/geociencias/informacoes-ambientais/cobertura-e-uso-da-terra/15831484 cobertura-e-uso-da-terra-do-brasil.html $?=\& \mathrm{t}=$ downloads..$($ accessed 17 June 2020) 485 ICMBio. 2018. Livro Vermelho da Fauna Brasileira Ameaçada de Extinção: Volume V-Anfibios. 486 Brasília, Distrito Federal, Brazil: Instituto Chico Mendes de Conservação da 487 Biodiversidade/MMA-Ministério do Meio Ambiente.

488 IUCN Red List of Threatened Species. 2010. e.T57250A11609155. Available at: 489 https://dx.doi.org/10.2305/IUCN.UK.2010-2.RLTS.T57250A11609155.en. Downloaded on 02 $490 \quad$ June 2020.

Kleyer M, Dray S, Bello Fd, Leps J, Pakeman RJ, Strauss B, Thuiller W, Lavorel S. 2012. Assessing species and community functional responses to environmental gradients: which multivariate methods? Journal of Vegetation Science 23:805-821.

Klink CA, Machado RB. 2005. Conservation of the Brazilian cerrado. Conservation biology 495 19:707-713.

Kopp K, Signorelli L, Bastos RP. 2010. Distribuição temporal e diversidade de modos reprodutivos de anfíbios anuros no Parque Nacional das Emas e entorno, estado de Goiás, Brasil. Iheringia Série Zoologia 100:192-200. environmental quality of the Southern Atlantic Rainforest. J Photochem Photobiol B 165:174181. 10.1016/j.jphotobiol.2016.10.025 
502 Lebreton J, Chessel D, Richardot-Coulet M, Yoccoz N. 1988. L'analyse des relations espèces503 milieu par l'analyse canonique des correspondances. II. Variables de milieu qualitatives. Acta 504 Oecologia Generalis 9:137-151.

505 Mizell S. 1965. Seasonal changes in energy reserves in the common frog, Rana pipiens. Journal 506 of Cellular and Comparative Physiology 66:251-258.

507 Newbold T, Hudson LN, Hill SL, Contu S, Lysenko I, Senior RA, Borger L, Bennett DJ, Choimes 508 A, Collen B, Day J, De Palma A, Diaz S, Echeverria-Londono S, Edgar MJ, Feldman A, Garon 509 M, Harrison ML, Alhusseini T, Ingram DJ, Itescu Y, Kattge J, Kemp V, Kirkpatrick L, Kleyer 510 M, Correia DL, Martin CD, Meiri S, Novosolov M, Pan Y, Phillips HR, Purves DW, Robinson 511 A, Simpson J, Tuck SL, Weiher E, White HJ, Ewers RM, Mace GM, Scharlemann JP, Purvis 512 A. 2015. Global effects of land use on local terrestrial biodiversity. Nature 520:45-50. $513 \quad 10.1038 /$ nature 14324

514 de Oliveira C, Franco-Belussi L. 2012. Melanic pigmentation in ectothermic vertebrates: 515 occurrence and function. In: Ma X-P, and Sun X-X, eds. Melanin: Biosynthesis, functions and 516 health effects. Hauppauge: Nova Science Publisher, 213-225.

517 Overbeck GE, Vélez-Martin E, Scarano FR, Lewinsohn TM, Fonseca CR, Meyer ST, Müller SC, 518 Ceotto P, Dadalt L, Durigan G, Ganade G, Gossner MM, Guadagnin DL, Lorenzen K, Jacobi 519 CM, Weisser WW, Pillar VD, Loyola R. 2015. Conservation in Brazil needs to include non520 forest ecosystems. Diversity and Distributions 21:1455-1460. 10.1111/ddi.12380

521 Parr CL, Lehmann CE, Bond WJ, Hoffmann WA, Andersen AN. 2014. Tropical grassy biomes: 522 misunderstood, neglected, and under threat. Trends In Ecology \& Evolution 29:205-213. $523 \quad 10.1016 /$ j.tree.2014.02.004 
524 Peres-Neto PR, Dray S, ter Braak CJF. 2017. Linking trait variation to the environment: critical

525 issues with community-weighted mean correlation resolved by the fourth-corner approach.

526 Ecography 40:806-816. 10.1111/ecog.02302

527 Pérez-Iglesias JM, Franco-Belussi L, Moreno L, Tripole S, de Oliveira C, Natale GS. 2016. Effects

528 of glyphosate on hepatic tissue evaluating melanomacrophages and erythrocytes responses in

529 neotropical anuran Leptodactylus latinasus. Environmental Science and Pollution Research $530 \quad 23: 9852-9861$.

531 Pérez-Iglesias JM, Natale GS, Soloneski S, Larramendy ML. 2018. Are the damaging effects

532 induced by the imazethapyr formulation Pivot ${ }^{\circledR} \mathrm{H}$ in Boana pulchella (Anura) reversible upon 533 ceasing exposure? Ecotoxicology and environmental safety 148:1-10.

534 Pérez-Iglesias JM, Franco-Belussi L, Natale GS, De Oliveira C. 2019. Biomarkers at different 535 levels of organisation after atrazine formulation (SIPTRAN 500SC®) exposure in Rhinella 536 schineideri (Anura: Bufonidae) Neotropical tadpoles. Environmental pollution 244:733-746.

537 Powers RP, Jetz W. 2019. Global habitat loss and extinction risk of terrestrial vertebrates under 538 future land-use-change scenarios. Nature Climate Change 9:323-329. 10.1038/s41558-019$539 \quad 0406-\mathrm{Z}$

540 R Core Team. 2020. R: a language and environment for statistical computing. R Foundation for 541 Statistical Computing, Vienna, Austria. Available at: http://www.R-project.org (accessed on 2 542 June 2020).

543 Reynolds J, Wesson K, Desbiez A, Ochoa-Quintero J, Leimgruber P. 2016. Using Remote Sensing 544 and Random Forest to Assess the Conservation Status of Critical Cerrado Habitats in Mato 545 Grosso do Sul, Brazil. Land 5. 10.3390/land5020012 
546 Rohr JR, McCoy KA. 2010. A qualitative meta-analysis reveals consistent effects of atrazine on

547 freshwater fish and amphibians. Environmental health perspectives 118:20-32.

548 Santos LRDS, Franco-Belussi L, Zieri R, Borges RE, De Oliveira C. 2014. Effects of thermal 549 stress on hepatic melanomacrophages of Eupemphix nattereri (Anura). The Anatomical Record $550 \quad 297: 864-875$.

551 Schiesari L, Waichman A, Brock T, Adams C, Grillitsch B. 2013. Pesticide use and biodiversity 552 conservation in the Amazonian agricultural frontier. Philos Trans $R$ Soc Lond B Biol Sci $553 \quad 368: 20120378.10 .1098 /$ rstb.2012.0378

554 Sichel G, Scalia M, Mondio F, Corsaro C. 1997. The amphibian Kupffer cells build and demolish 555 melanosomes: an ultrastructural point of view. Pigment cell research 10:271-287.

556 Silva HSV, Loiola C, Pereira SRF, Santos RL, De Andrade GV, Nunes GS. 2013. Toxicidade 557 aguda e genotoxicidade do agrotóxico comercial Folisuper 600br a girinos de Physalaemus 558 cuvieri (Anura: Leiuperidae). Pesticidas: Revista de Ecotoxicologia e Meio Ambiente 23:1-10. $559 \quad 10.5380 /$ pes.v23i0.34994.

560 Song XP, Hansen MC, Stehman SV, Potapov PV, Tyukavina A, Vermote EF, Townshend JR. 561 2018. Global land change from 1982 to 2016. Nature 560:639-643. 10.1038/s41586-018-04115629

563 Terman A, Brunk UT. 2004. Lipofuscin. The international journal of biochemistry \& cell biology $564 \quad 36: 1400-1404$.

565 Ter Braak CJ, Peres-Neto P, Dray S. 2017. A critical issue in model-based inference for studying 566 trait-based community assembly and a solution. PeerJ 5:e2885. 10.7717/peerj.2885 
567 ter Braak CJF, Šmilauer P, Dray S. 2018. Algorithms and biplots for double constrained 568 correspondence analysis. Environmental and Ecological Statistics 25:171-197. $569 \quad 10.1007 / \mathrm{s} 10651-017-0395-\mathrm{x}$

570 ter Braak CJ, Šmilauer P. 2018. Canoco reference manual and user's guide: software for ordination 571 (version 5.10). Biometris, Wageningen University \& Research.

572 Valente CR. 2006. Caracterização geral e composição florística do cerrado. In: Guimarães LD, 573 Silva MAD, Anacleto TC, eds. Natureza viva cerrado-caracterização e conservação. Goiânia: 574 Universidade Católica de Goiás, 19-54. 
Figure 1

Fig. 1. Map showing the location of sampling sites in Goiás, Central Brazil.

Points represent ponds sampled.

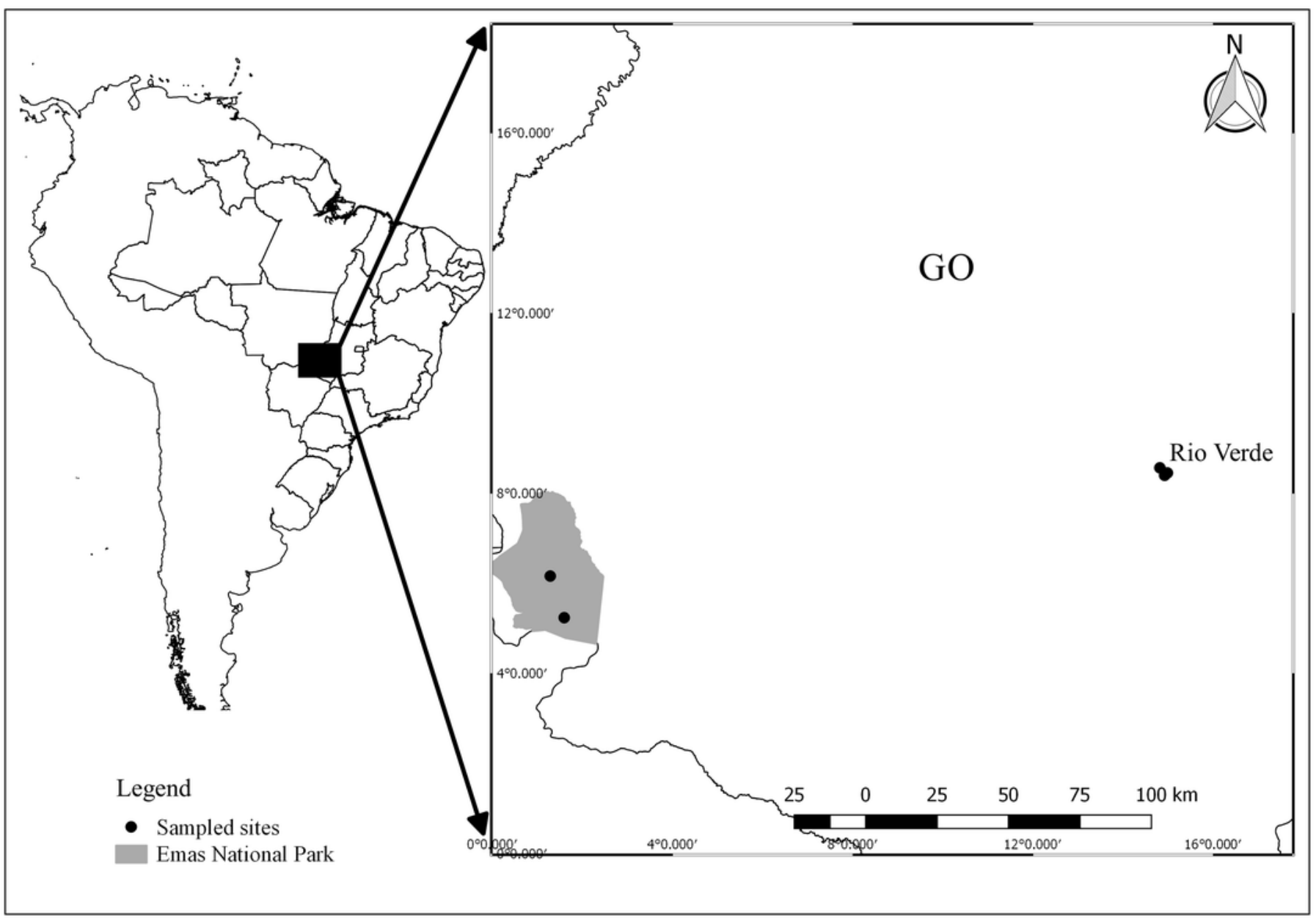




\section{Figure 2}

Ternary plot showing the relative proportion of the area of each substance in the five frog species considering all sampling sites.

Small points represent individual measurements, while the large dot represents the mean of each substance for each species.

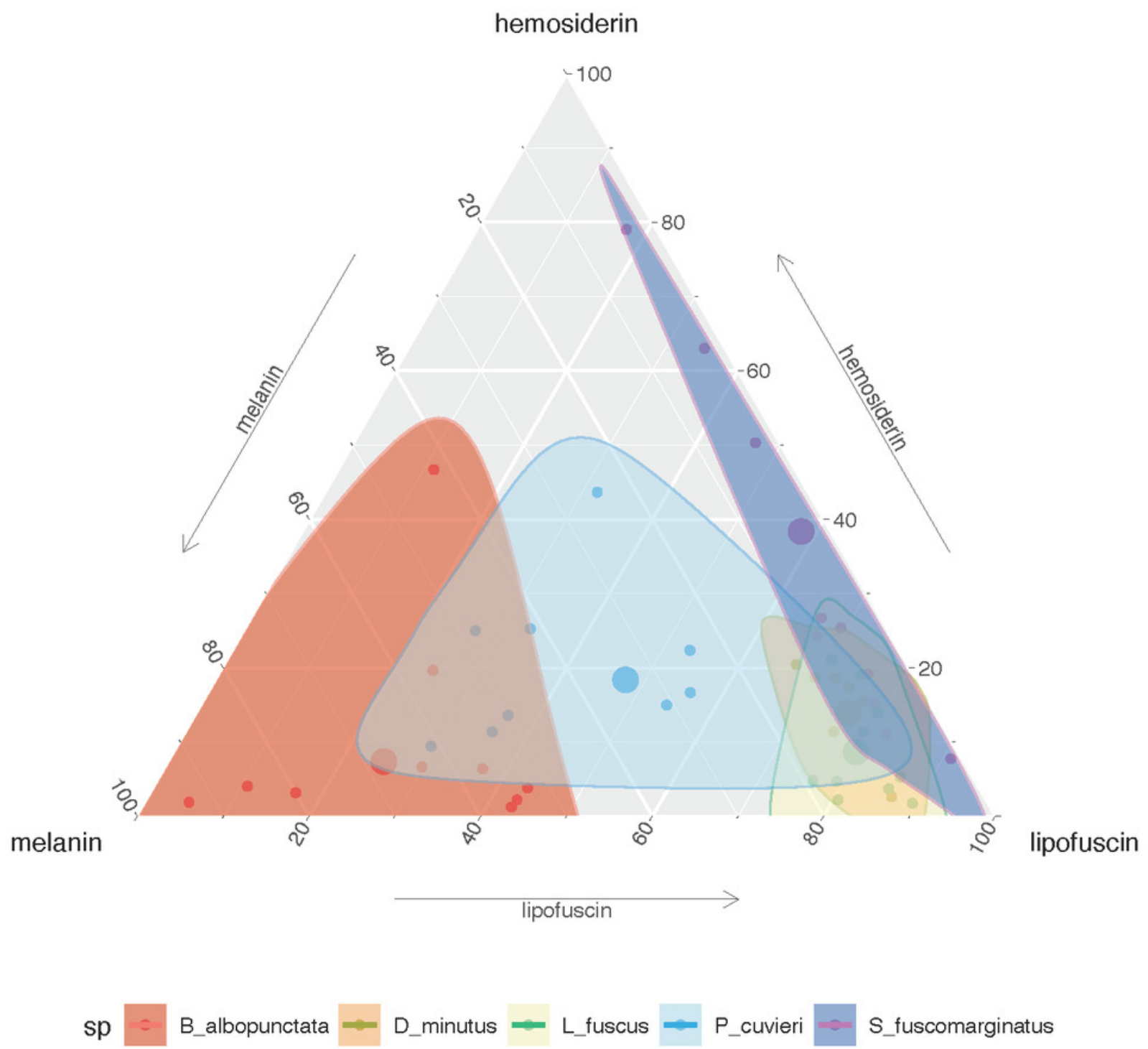




\section{Figure 3}

Fig. 3. Plate with histological sections showing differences in liver pigments for the three species that had the highest change in mean pigment area between the two sampling regions.

(A-E) Physalaemus cuvieri. (F-J) Scinax fuscomarginatus. (K-O) Boana albopunctata. Dark blue color corresponds to hemosiderin, while grayish blue color corresponds to lipofuscin. Legend: arrow $=$ hemosiderin, arrowhead $=$ lipofuscin; asterisk $=$ melanin. Scale bar $=25 \mu \mathrm{m}$.

Staining: Schmorl's solution for lipofuscin and acid solution of ferrocyanide for hemosiderin. Scinax fuscomarginatus (F) photo credit: Mario A. Sacramento.

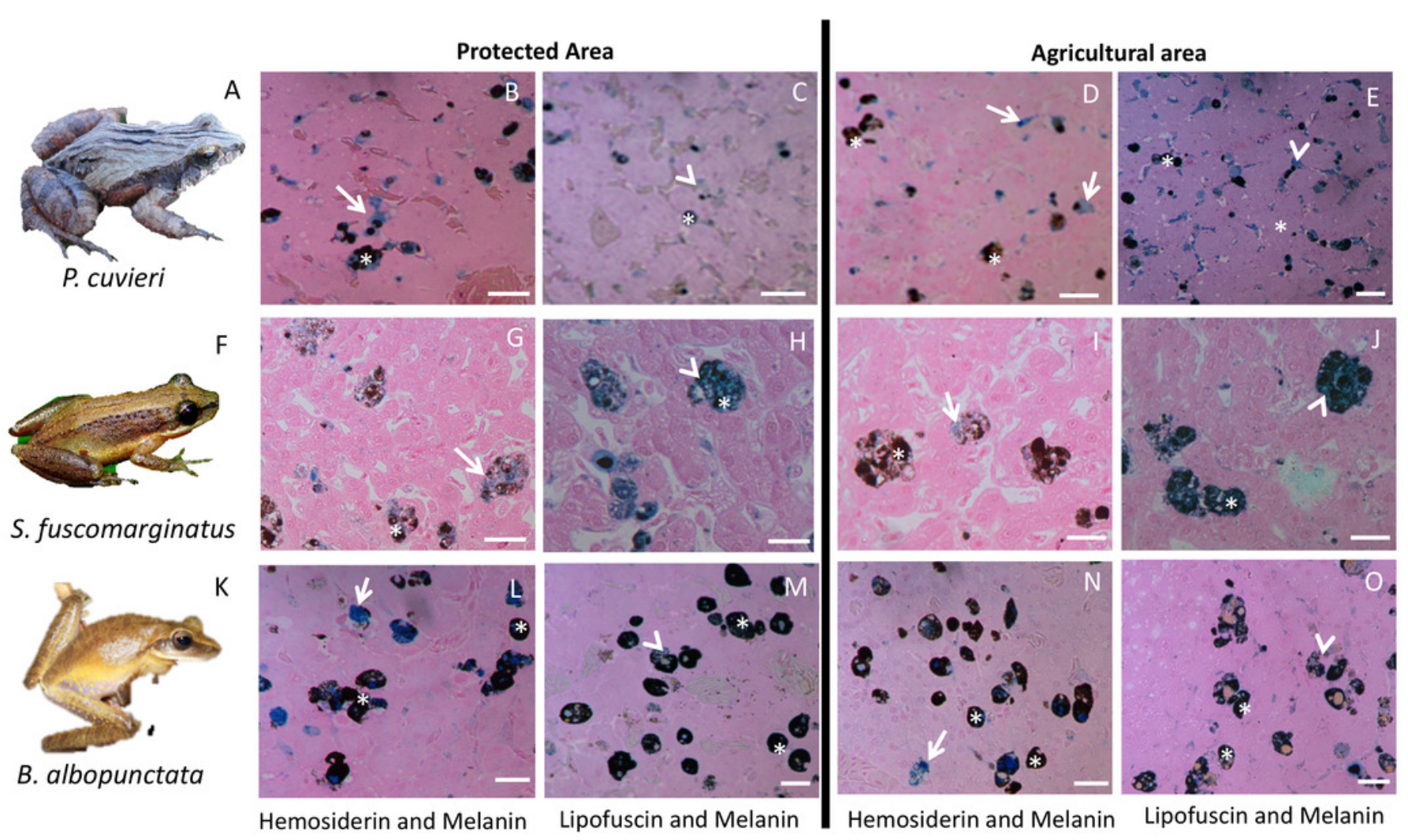


Figure 4

Fig. 4. Ordination diagram of double-constrained Correspondence Analysis.

Figure shows the relationships among species abundance, liver cell metabolic pigments, and land use classes. Arrow length indicates the importance of variables for the construction of ordination axes.

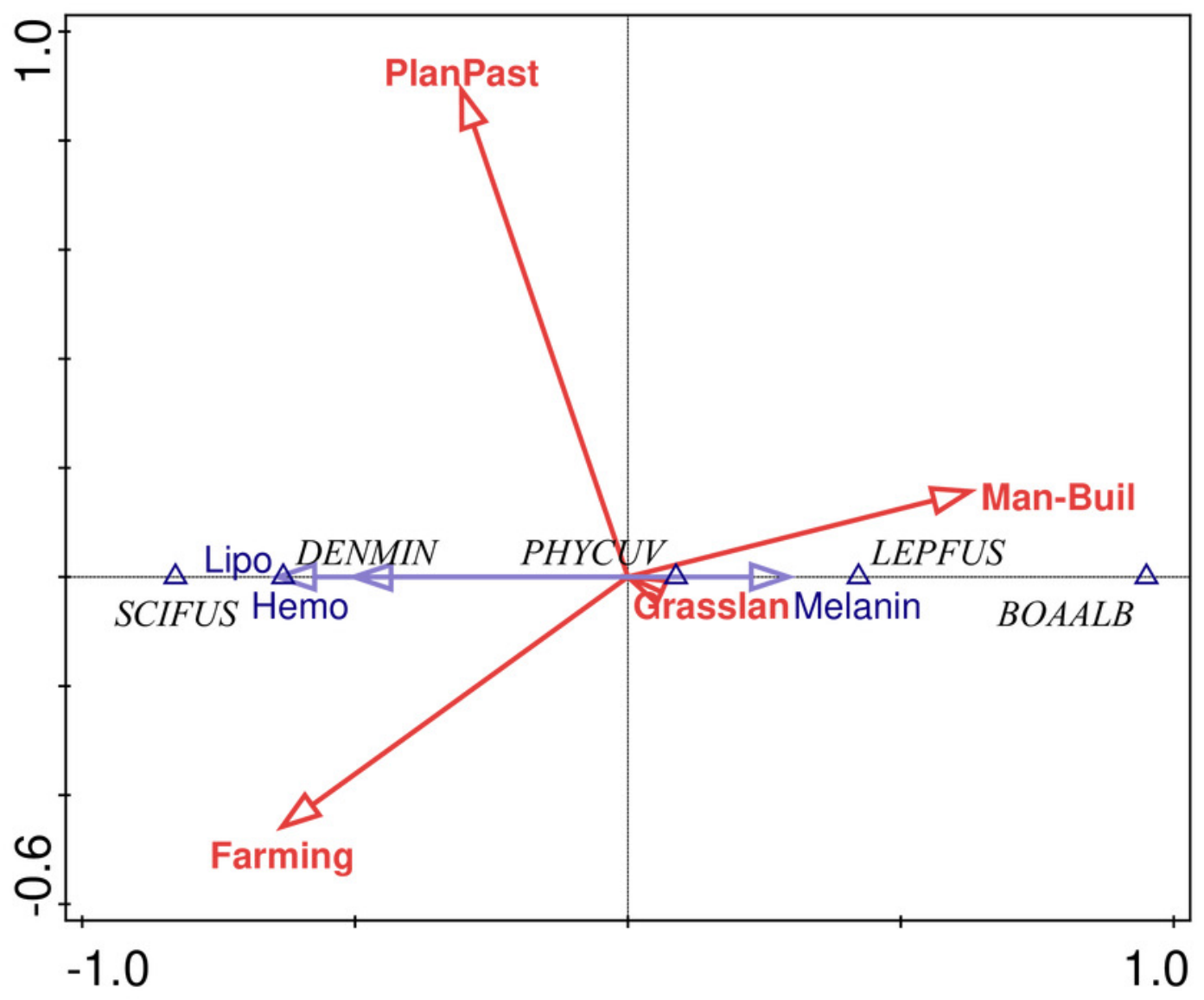




\section{Table $\mathbf{1}$ (on next page)}

Fourth-corner correlation calculated between species traits (area of each substance in the liver) and environmental variables (percentage of land use type in a $500 \mathrm{~m}$ buffer around ponds). 


\begin{tabular}{lrrr}
\hline & Melanin & Hemosiderin & Lipofuscin \\
\hline Natural pasture & 0.139 & -0.276 & -0.252 \\
Man-made building area & -0.033 & -0.188 & -0.228 \\
Planted pastures & 0.473 & -0.135 & -0.267 \\
Agriculture & -0.386 & 0.721 & 0.78 \\
\hline
\end{tabular}

1 